\title{
Política baseada em evidências: a busca de novas opções para a Odontologia brasileira
}

Arrisco dizer que a satisfação do cirurgião-dentista brasileiro com o estado atual da Odontologia é bem inferior que a de 20 anos atrás. Também arrisco prever que desceremos muito antes de alterar essa trajetória negativa. Entretanto, esse cenário contrasta com grandes conquistas que realizamos. Temos escolas que rivalizam com as melhores do planeta e pesquisadores que não necessitam de cooperação internacional para se posicionar na crista da onda do conhecimento. Como esses quadros podem coexistir? E mais, o que podemos fazer para buscar melhoras?

A ascensão da Odontologia brasileira ao patamar que hoje possui foi resultado de um amálgama de fatores. Inicialmente, os meios eletrônicos nivelaram os países no quesito acesso à informação. Na sequência, a grande competição no mercado brasileiro fez valer um processo de seleção natural. Nosso mercado de trabalho não é tranquilo como o americano. No competitivo mercado brasileiro, para ser considerado bom, o profissional precisa ser excepcional.

A competição intensa teve outros efeitos positivos. Em especial, aumentou o acesso da população aos tratamentos odontológicos em geral. Entretanto, muitos concordam que ela já atingiu - há algum tempo - o status de predatória. Nesse cenário, como salientado por James M. Buchanan, prêmio Nobel de Economia em 1986, a competição passa a ser perniciosa. Perdem, nesse caso, a Odontologia como um todo e a população brasileira.

A Odontologia perde não apenas com o excessivo achatamento dos honorários profissionais; ainda que valha lembrar que honorário é uma palavra que tem vínculo etimológico com honra. Perde também porque esse efeito acarreta a fuga de jovens talentos da profissão.

Por seu lado, a população que no passado se beneficiou com o aumento do acesso aos serviços odontológicos de saúde, hoje presencia uma tendência de queda na qualidade dos mesmos serviços.

É óbvio que precisamos de guinadas no curso das políticas relacionadas à Odontologia no Brasil. É também igualmente importante que essas mudanças atendam não apenas aos interesses dos cirurgiões-dentistas. Elas têm que representar o melhor equilíbrio possível entre os interesses dos profissionais e os da população, tendo os últimos peso maior.

Várias propostas vêm sendo ventiladas. Alguns defendem que o reforço na qualidade da educação superior seria, por si, capaz de sanar esses problemas. Faculdades de qualidade comprovadamente inadequada seriam fechadas e, como resultado, apenas bons profissionais emergiriam no mercado de trabalho. Entretanto, é crivel esse cenário no Brasil?

Outros tantos defendem uma prova de proficiência, à semelhança da prova da Ordem dos Advogados do Brasil. Os defensores dessa estratégia alegam que somente os profissionais com comprovada qualidade entrariam no mercado de trabalho e, dessa forma, garantir-se-ia a qualidade da assistência odontológica. Por outro lado, não seria essa uma forma de reserva de mercado? E os profissionais que não forem exitosos nessa prova, o que seria feito deles?

Talvez a melhor solução para os problemas da Odontologia brasileira advenha de uma combinação das duas propostas mais discutidas. Ou mesmo, pode ser que uma terceira e mais ideal sugestão apareça. Porém, como definir qual a estratégia que deverá ser adotada?

Vivemos a era da Odontologia Baseada em Evidências. Essa proposta de conduta visa permitir que propiciemos o melhor resultado de tratamento possivel para nossos pacientes. Se assim o é, nada mais natural do que busquemos desenvolver políticas fundamentadas não no "achismo", mas em estudos que analisem o mercado de trabalho odontológico brasileiro nas várias especialidades e a satisfação dos cirurgiões-dentistas e da população com a Odontologia. Em outras palavras, precisamos nesse momento desenvolver Políticas Baseadas em Evidências.

Para que alteremos o curso que a Odontologia brasileira possui hoje, e tenhamos opções no futuro - e não apenas um destino -, a comunidade científica odontológica em nosso país precisa voltar sua atenção para essas questões. Estudos dessa natureza serão os argumentos que pressionarão e nortearão Conselhos, Associações e o Congresso Nacional em busca de um futuro melhor.

Por fim, os mesmos preceitos de difusão de conhecimento por meios eletrônicos, que nos nivelaram com outros países no acesso à informação, fazem agora que a Revista Dental Press de Ortodontia e Ortopedia Facial introduza mais um avanço. A partir do próximo número teremos artigos no formato somente eletrônico. Esses trabalhos gozarão de prazos de publicação mais curtos, e estarão disponíveis com conteúdo integral na base de dados SciELO, gozando do mesmo prestígio que uma publicação impressa possui.

Bons estudos.

Jorge Faber

Editor chefe

faber@dentalpress.com.br 